Paper accepted for publication in:

The Journal of Product Innovation Management

\title{
Achieving Customer Satisfaction through Integrated Products and Services: An Exploratory Study
}

\section{Authors:}

Jawwad Z. Raja, Copenhagen Business School

Dorota Bourne, Queen Mary University of London

Keith Goffin, Cranfield School of Management

Mehmet Çakkol, Cranfield School of Management

Veronica Martinez, Cranfield School of Management

\section{Corresponding Author:}

Dr. Jawwad Z. Raja

Department of Operations Management

Copenhagen Business School

Solbjerg Plads 3

2000 Frederiksberg

Denmark

Email:jr.om@cbs.dk 


\title{
Achieving Customer Satisfaction through Integrated Products and Services: An Exploratory Study
}

\begin{abstract}
Complex products such as manufacturing equipment have always needed maintenance and repair services. Increasingly, leading manufacturers are integrating products and services to generate increased revenues and achieve customer satisfaction. Designing integrated products and services requires a different approach to new product development and a clear understanding of how customers perceive the value they obtain from actual usage of products and services-so-called value-in-use. However, there is a lack of research on integrated products and services and how they impact customer satisfaction.

An exploratory study was undertaken to understand customers' views on integrated products and services and the value-in-use derived from such offerings. As value-in-use and its impacts are complicated concepts, a technique from psychologyRepertory Grid Technique-was used to gather data in 33 interviews. The interviews allowed a deep understanding of customer views on integrated products and services to be obtained and a systematic analysis identified the key attributes of value-in-use. In order to probe further, the data were then analysed using Honey's procedure, which identified the impact of the attributes of value-in-use on customer satisfaction. Two key attributes-relational dynamic and access-were found to have the most influence on customer satisfaction. This article contributes to the innovation field by identifying customer needs for integrated products and services and how these impact customer satisfaction. These are key points and need to be fully considered by managers during new product and service development. Similarly, the article identifies a number of important areas for further research.
\end{abstract}

Keywords: integrated products and services; customer solutions; servitization; productservice systems; after-sales service; new product and new service development; customer needs/satisfaction; Repertory Grid; Honey’s procedure

\section{Acknowledgements}

The authors acknowledge the funding and support of the UK Engineering and Physical Science Research Council Grant (EPSRC/IMRC-144), through the Cranfield Innovative Manufacturing Research Centre. We acknowledge the support of all members of the PSS Value team at Cranfield University and special thanks to Dr Mark Johnson for his helpful insights into the literature on integrated products and services. Lastly, we are grateful for the support received from Ayten Alibaba and Joerg Ries. 


\section{Achieving Customer Satisfaction through Integrated Products and Services: An Exploratory Study}

\section{INTRODUCTION}

Complex products such as manufacturing equipment require significant after-sales service, for example maintenance and repair. Such services are essential for achieving customer satisfaction, as without them, equipment may fail. The importance of providing appropriate services has long been recognized (e.g. Lele and Karmarkar, 1983; Wise and Baumgartner, 1999) and therefore, leading manufacturers provide a range of after-sales services including installation, operator training, documentation, maintenance and repair, warranty, and upgrades (Goffin, 1998). Manufacturers need to integrate their products and services (Oliva and Kallenberg, 2003; Shankar et al., 2010), to provide what have variously been referred to as integrated solutions (Davies, 2004), customer solutions (Tuli et al., 2007), servitization (Vandermerwe and Rada, 1988), or product service systems (Baines et al., 2009). Integrated products and services can lead to increased revenues (Bundschuh and Dezvane, 2003; Cohen et al, 2006) and customer satisfaction (Armistead and Clark, 1992; Lele and Sheth, 1987). It has been acknowledged that designing requires a fresh approach to new product development (NPD) (Baines et al, 2007; Sundin et al., 2009). However, what needs to be done differently is unclear because, as academics have recognized, there has not been enough research in this area (Hull and Cox, 1994; Goffin and New, 2001; Bundschuh and Dezvane, 2003; Creusen, 2011).

The innovation literature typically discusses products and services separately (Windahl et al., 2004). The vast majority of research has focused on products (e.g. Dröge et al., 2000; Franke and Piller 2004; Langerak et al., 2004; Petersen et al., 2003) but there 
is a stream on new service development (NSD) (e.g. Storey and Easingwood, 1998; Song et al., 2000; Menor et al., 2002; Carbonell et al., 2009; Zomerdijk and Voss, 2011). In addition, some studies have highlighted the differences between NPD with NSD (e.g. Menor et al., 2002; Karniouchina et al., 2006; Menor and Roth, 2007; Schleimer and Shulman, 2011). However, within a customer solutions context, it is not the differences between developing products and services that are important, rather it is how they can be aligned to lead to an integrated offering that addresses customer needs. Evidence of manufacturers integrating products and services can be traced as far back as the $1800 \mathrm{~s}$ (Schmenner, 2009) but customer needs for such combinations are not well understood. This is a gap, since understanding customer needs is fundamental to innovation (Griffin and Hauser, 1993) and achieving customer satisfaction in this context.

The literature on integrated products and services stresses that customers must derive maximum value from using products. However, value-in-use as it is termed (Woodruff, 1997; Vargo and Lusch, 2004; Woodruff and Flint, 2006) is a complex construct and researching it required a novel approach. Access to a European supplier of integrated offerings and its clients was obtained. Respondents from the client companies were interviewed using an approach from psychology—Repertory Grid Technique (e.g. Goffin and Koners, 2011)—to help them articulate their views on value-in-use. In total 33 interviews were conducted and systematically analyzed to identify the key attributes of integrated offerings. In addition, the Honey procedure for analyzing repertory grids (Honey, 1979) was used to understand the impact of value-in-use on customer satisfaction. The contribution of this article is therefore around identifying customer needs for integrated products and services, and how these impact customer satisfaction. 
This is crucial because "the unity between product and service should be taken into account during design" (Creusen, 2011, p. 407).

The remainder of this article is structured in five main sections. The first provides a comprehensive review of the literature, including the role of customer needs in NPD, and customer satisfaction. The next section on research design explains the two research questions and how Repertory Grid Technique was applied. The third section presents an example repertory grid, the multiple grids analysis and the analysis based on Honey's procedure. The "Discussion and Conclusions" section presents the contribution of the research, its limitations, areas for future research, and ramifications for managers. Finally, a summary of the research is given.

\section{LITERATURE REVIEW}

Companies that manufacture complex products have always needed to offer after-sales support, including the provision of spare parts and warranty services (Goffin, 1999). More recently, organizations have started to focus more attention on customer solutions-integrated product and service offerings (Tuli et al., 2007). The literature is ambiguous in that many different terms have been used. In this article the term integrated products and services will be used, as this best describes what customers require. Four main areas of the literature were identified as relevant:

- The importance of after-sales service.

- Articles indicating the need to move to integrated products and services.

- Studies of the role of customer needs in NPD and for integrated products and services.

- Research on how integrated products and services generate customer satisfaction. 


\section{The Importance of After-sales Services}

After-sales service is essential in order for customers to obtain maximum value from products (e.g. Lele and Karmarkar, 1983). Over the years, after-sales service has been variously referred to as product support, aftermarket support and customer support. In the past many firms have neglected after-sales and concentrated on products (Wise and Baumgartner, 1999; Cohen et al., 2006). This was a mistake because after-sales can be a major source of revenue (Berg and Loeb, 1990; Cohen et al., 2006; Hull and Cox, 1994; Knecht, et al 1993; Bundschuh and Dezvane, 2003; Oliva and Kallenberg, 2003); it creates customer satisfaction (Goffin, 1999; Vandermerwe, 1990); and leads to competitive advantage (Armistead and Clark, 1992; Desmet et al., 1998; Gebauer et al., 2011; Goffin, 1998; Hull and Cox, 1994; Loomba, 1998; Matthyssens et al., 2006; Penttinen and Palmer, 2007; Oliva and Kallenberg, 2003; Slack et al., 2004; Shepherd and Ahmed, 2000).

\section{From After-sales Services to Integrated Products and Services}

Manufacturers have been advised to provide more services (Wise and Baumgartner, 1999) and adopt a servitization strategy—providing bundles of goods and services to add value (Vandermerwe and Rada, 1988). Customer focused combinations of products and services require close links between manufacturers and their customers (Tuli et al., 2007; Santamaria et al., 2012) because the literature emphasizes that value is created by solutions customized to specific customer needs (cf. Foote et al., 2001; Gerstner, 2002; Davies, 2004; Davies et al., 2006). So manufacturers need to develop the capability to 
deliver such solutions (Davies, 2004; Storbacka, 2011). The term product service systems (PSS) first emerged in the late 1990s (Goedkoop et al., 1999) in the field of sustainability (Mont, 2002; Manzini and Vezzoli, 2003). A stream of literature has developed since, which defines PSS as "an integrated product and service offering that delivers value-inuse" (Baines et al, 2007, p. 1545). PSS researchers have proposed three categories of product-service combinations (Tukker, 2004; Baines et al., 2009). The first category, Product-oriented services are provided at the customer's expense, to support a product which has been purchased from a manufacturer. These are support services, such as repair and sale of spare parts, which generate for manufacturers but represent unexpected costs for customers. Use-oriented services involve the lease of a product, so that customers gain the benefits of the product without full ownership. Use-oriented services typically demand some integration as processes are outsourced by the customer to the supplier (cf. Windahl and Lakemond, 2010). Finally, Result-oriented services involve an agreement specifying the end-result to be delivered, not the technical specifications of the product and a price is paid for achieving the result, with the manufacturer determining the most cost-effective means of delivery.

Although many different terms are used, there is much agreement in the different streams of literature. For example, many papers recognize that integrated products and services are required to meet customer needs (e.g. Brady et al., 2005; Davies et al., 2006; Johnstone et al., 2009; Shelton, 2009) and provide value-in-use (Macdonald et al., 2011). The term value-in-use indicates that customers can only evaluate the value of product and service combinations through usage (cf. Vargo and Lusch, 2004). It should be noted that value-in-use may be very different to the perceived value at the time of purchase. 
Although the importance of understanding value-in-use has been recognized (Flint and Mentzer 2006; Vargo and Lusch 2004; Ostrom et al., 2010), there is very little empirical evidence on how customers experience integrated products and services.

\section{Understanding Customer Needs for Integrated Products and Services}

There is widespread recognition of the importance of involving customers in both NPD (e.g. Cooper, 2001; Griffin and Hauser, 1993) and NSD (e.g. Alam, 2006; Carbonell et al., 2009; Menor et al., 2002). This is because development of superior products or services requires a deep understanding of customer needs (Griffin and Hauser, 1993). Of the studies within a business-to-business context, most stress that customer involvement is beneficial to NPD (e.g. Souder, 1987; von Hippel 1988).

Interestingly, the integrated products and services literature has two significant limitations. Firstly, as mentioned earlier, it does not describe typical customer needs. Secondly, although there is a vast literature on the process of NPD including the ubiquitous Stage-Gate process (Cooper, 2001), the integrated products and services literature only makes generic comments on how this process should be changed to accommodate integrated products and services. Morelli (2003) recommended an in-depth analysis of user requirements whereas Maxwell and van der Vorst (2003) proposed that product design should consider the whole lifecycle of product usage. Integrated products and services entail long-term relationships between manufacturers and their customers (Gulati and Kletter, 2005; Windahl and Lakemond, 2006; Tuli et al., 2007; Lindberg and Nordin, 2008; Bastl et al., 2012), with customer expectations changing as relationships develop (Macdonald et al., 2011). So it is imperative for solution providers to understand 
the evolving needs of customers (cf. Vandermerwe, 2000; Penttinen and Palmer, 2007) in order to deliver suitable outcomes (Lindberg and Nordin, 2008; Johnstone et al., 2009). Such outcomes may vary considerably across different industries.

\section{Integrated Products and Services and Customer Satisfaction}

Much of the research on customer satisfaction, for example in the NSD literature, originates from a marketing perspective and focuses on the business-to-consumer context. On the other hand, integrated products and services are predominately set within a business-to-business context. Their importance for achieving customer satisfaction is mentioned in the literature on both after-sales (e.g. Goffin and New, 2001) and customer solutions (e.g. Markeset and Kumar, 2003; Gebauer et al., 2011; Macdonald et al., 2011). Manufacturers which match products and services to customer needs achieve higher levels of customer satisfaction (Anderson and Sullivan, 1993; Zeithaml et al., 1990). Cannon and Perreault (1999) show that customer satisfaction depends on the relationship with the manufacturer and, similarly, customer satisfaction is "not only decided by value received... [but also] by the quality of the interaction and relationship experience throughout the service life of the product" (Markeset and Kumar, 2003, p. 385). In this sense, customer satisfaction is strongly dependent on the relational dynamic between customers and manufacturers (Selnes, 1998; Tikkanen et al., 2000).

\section{Conclusions on the Literature}

Four main conclusions emerged: 
- After-sales service allows manufacturers to generate extra revenues, increase customer satisfaction and gain competitive advantage.

- The more recent literature advocates integrated products and services, which allow customers to derive value-in-use.

- The literature considers the identification of customer needs to be an essential part of NPD. However, there is little empirical evidence on customer needs related to integrated products and services, or how customers perceive value-in-use.

- Research is needed to identify how value-in-use impacts customer satisfaction, particularly in business-to-business contexts.

\section{RESEARCH DESIGN}

The extant literature on integrated products and services has not explored how customers derive value-in-use from integrated products and services. Therefore, two research questions were chosen:

1) What are the key attributes of value-in-use for integrated products and services? [RQ1]

\section{2) How do the attributes of value-in-use impact customer satisfaction? [RQ2]}

Figure 1 gives an overview of the research design. Access to a large multinational manufacturer was secured, which will be referred to as 'ProServ'. This original equipment manufacturer (OEM) provides products and services and three initial meetings with ProServ managers gave an understanding of their offerings, customers and business challenges (including their aim to better understand customer needs). Interestingly, the 
company's focus on customer needs was found to mirror the research questions, showing that the research not only addressed gaps in the literature but also the needs of practitioners.

\section{Sample of Companies and Respondents}

After discussing ProServ's business challenges, the next stage was negotiating access to four of its clients. These were multinational manufacturers from the following sectors: medical equipment (Customer A), pharmaceuticals (Customer B), insulation equipment (Customer C), and a specialist metal manufacturer (Customer D). They were selected to represent a variety of customer needs. The range of individual respondents at the companies included: maintenance technicians, engineering co-ordinators, technical services managers, purchasing managers, procurement directors, maintenance managers, engineering directors and finance directors. 


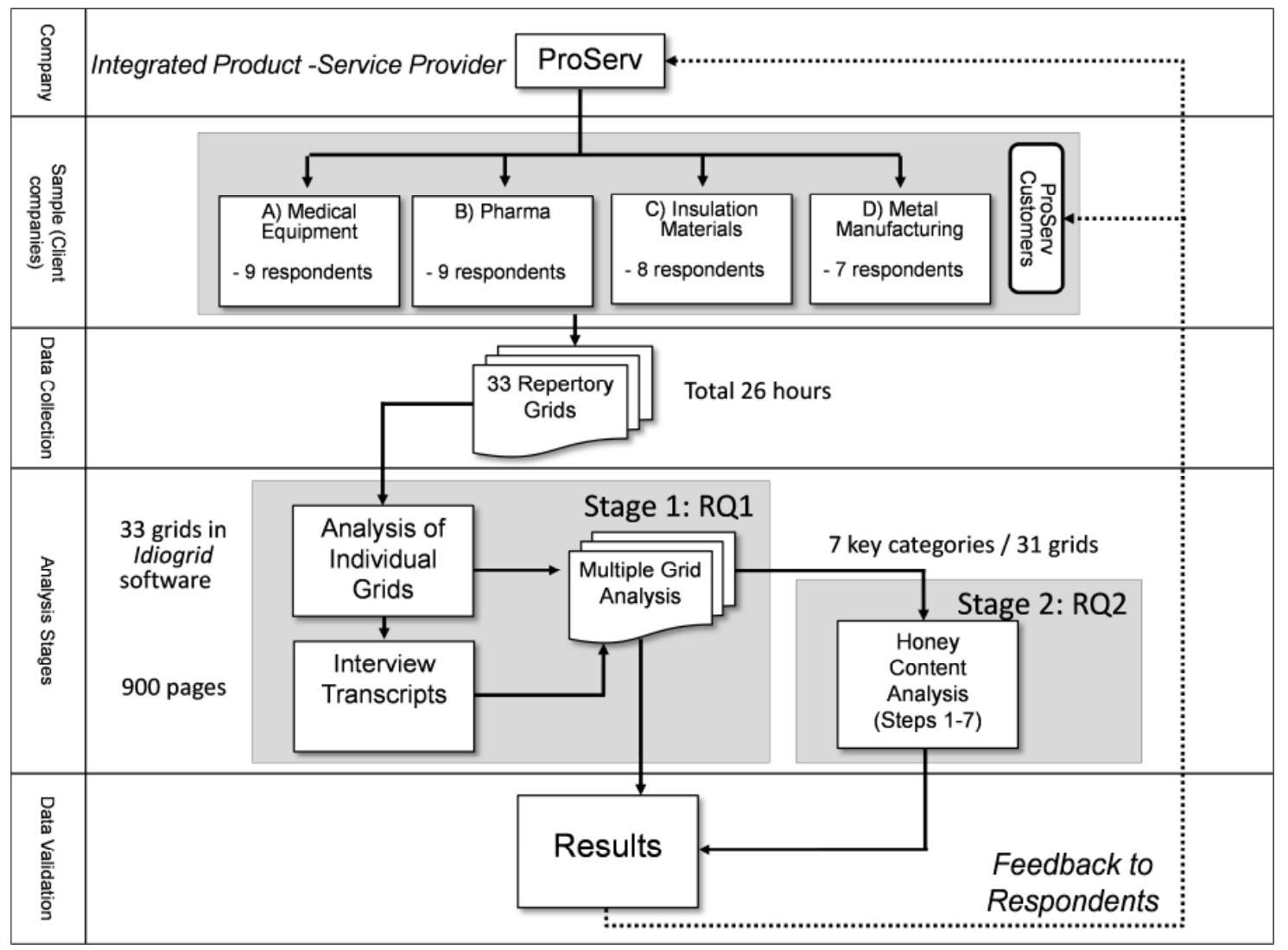

Figure 1: Overview of Research Design

\section{Data Collection-the Repertory Grid Technique}

Value-in-use and customer satisfaction are complex constructs involving aspects which are intangible and therefore difficult to describe. Consequently, Repertory Grid Technique was selected as it stimulates respondents to discuss complex topics in their own words, without researcher bias. The Repertory Grid (also commonly referred to as 'Repgrid') Technique, is a grounded, interpretivist approach (Kelly, 1955), which has been used successfully in many areas of management research. These include quality control (Dobosz-Bourne, 2006; Dobosz-Bourne and Jankowicz, 2003), NPD (Goffin and Koners, 2011), industrial design (Micheli et al., 2012), human resource management and marketing (Stewart and Stewart, 1982). 
A unique characteristic of Repgrid is that it captures personal meaning through both qualitative and quantitative analysis. Those who focus on its qualitative side, see it as a tool for encouraging reflexivity on the part of the respondent, helping to identify the respondent's perceptions of the world, rather than influencing them to adopt the interviewer's terminology as is often the case in traditional interviews (Bell, 2009). For this reason, the technique has become popular with researchers aiming for an in-depth understanding of respondents' construing, including their tacit knowledge and taken-forgranted assumptions (Jankowicz, 2001).

Several studies presented in this journal have applied Repgrid using quantitative analysis to identify key attributes (see Koners and Goffin, 2007; Goffin and Koners, 2011; Micheli et al., 2012). The quantitative approach was relevant to this research since RQ1 aimed to explore the key attributes of value-in-use for integrated products and services as identified by the respondents rather than imposing the terminology from the literature (which remains diverse and ambiguous).

The interviews followed a standard triadic elicitation process, the terminology of which is clearly explained by Jankowicz (2004). Each respondent was asked to name six to ten suppliers of industrial maintenance services and products and the seven elements of customer support outlined by Goffin and New (2001) were used in this discussion. With each triad presented to the respondent, the question posed was: "Can you think of any ways in which two of these suppliers are similar to each other and different from the third in terms of the outcomes you get?" This stimulated respondents to discuss how they perceived the usage of products and services. Different triads were then presented to the 
interviewee with the same question asked each time. Further details of the interviews are given in Goffin et al. (2012).

Data collection took place across the United Kingdom and Ireland at the four companies' premises. In total, 33 Repgrid interviews were conducted, lasting between 45 and 90 minutes; a total of over 26 hours. The interviews were transcribed verbatim resulting in over 900 pages of transcripts (see Figure 1).

\section{Data Analysis}

The analysis of the data was conducted in two distinct stages, each aligned to a research question (see also Figure 1):

Stage 1: Analysis of Repertory Grids to Answer RQ1. Individual and multiple grid analysis procedures as outlined in the extant literature (e.g. Goffin and Koners, 2012) were used to determine the most important attributes of value-in-use for integrated products and services.

Stage 2: Honey Content Analysis to Answer RQ2. The most important attributes of valuein-use identified in Stage 1 were then subjected to further analysis using the Honey procedure. This is a rather infrequently used and reported method which was enhanced using the developments proposed by Shcheglova (2009). As it is easier to explain Honey procedure using actual data, the explanation is given in the Results Section. (This is the first article published to report this type of analysis in detail.)

\section{Validation of Results}


In addition to a number of reliability checks on the data (described in the Results sections), the overall findings were validated through discussions with ProServ and its four customers (see dotted feedback loop in Figure 1). In these discussions, respondents and ProServ confirmed that the findings reflected their views, demonstrating face validity.

\section{RESULTS OF STAGE 1: IDENTIFYING KEY ATTRIBUTES}

To answer RQ1, the analysis was conducted in two steps, replicating the approach of Goffin et al (2006):

- Analysis of individual repertory grids.

- Multiple grid analysis.

\section{Analysis of Individual Grids}

Figure 2 shows an example grid from Company A Respondent 9. It has eight elicited personal constructs (e.g. "Good quality product and service" and "Effective - get desired results"), which are the respondent's perceptions of value-in-use. In addition, there is one so-called supplied construct "satisfied - dissatisfied", which was supplied by the researchers. Each construct was rated on a scale of 1-5. These ratings are recorded in the horizontal rows of the grid. For example, the ratings on the elements for Construct Number 2 "wider variety of product and service offerings" range from 1-5, whereas ratings on the elements for Construct Number 8 "good customer support" range only from 1-2 (indicating the good performance of all suppliers). 
Each individual grid was input into Idiogrid software (www.idiogrid.com) and the variability, which is an indicator of the more important constructs (Smith, 1986), calculated. Note that Figure 2 also includes gray shaded areas, which are from the Honey Content Analysis discussed later.

\section{Multiple Grid Analysis}

The multiple grid analysis procedure outlined by Goffin and Koners (2011) was adopted, which involved seven steps. First, two sets of construct cards were produced; on each card was a construct and its counter pole with a detailed description or explanation of the construct from the transcripts. Second, two researchers $\left(\mathrm{R}_{1}\right.$ and $\left.\mathrm{R}_{2}\right)$ working independently coded the construct cards separately into preliminary coding categories. Third, a reliability table comparing the two researchers' preliminary coding categories was prepared (see Goffin et al., 2012 for more detail). Fourth, inter-rater reliability (IRR) checks showed a $48 \%$ agreement between the two researchers (see Table 1). Fifth, the two researchers $\left(\mathrm{R}_{1}\right.$ and $\left.\mathrm{R}_{2}\right)$ discussed the discrepancies and produced 29 enhanced category definitions. Sixth, the two researchers $\left(\mathrm{R}_{1}\right.$ and $\left.\mathrm{R}_{2}\right)$ then re-coded the constructs independently and in parallel into the enhanced categories (cf. Jankowicz, 2004), resulting in an IRR of $86 \%$. Lastly, two independent researchers $\left(\mathrm{R}_{3}\right.$ and $\left.\mathrm{R}_{4}\right)$ then coded the constructs into the enhanced coding categories to check the reliability of the process. 


\begin{tabular}{|c|c|c|c|c|c|c|c|c|c|}
\hline \multirow{2}{*}{$\begin{array}{l}\text { Construct } \\
\text { Number }\end{array}$} & \multirow{2}{*}{ Elicited Constructs } & \multicolumn{6}{|c|}{ Elements } & \multirow{2}{*}{ Construct Poles } & \multirow{2}{*}{$\begin{array}{l}\text { H-I-L } \\
\text { Index }\end{array}$} \\
\hline & & Supplier 1 & Supplier 2 & Supplier 3 & Supplier 4 & Supplier 5 & Supplier 6 & & \\
\hline \multirow[t]{2}{*}{1} & $\begin{array}{l}\text { Good quality product and } \\
\text { service }\end{array}$ & 4 & 2 & 1 & 2 & 1 & 1 & Premature failures & $\mathrm{H}$ \\
\hline & \multicolumn{2}{|c|}{ Sum of differences: 1} & \multicolumn{2}{|c|}{ imilarity score: $92 \%$} & \multicolumn{4}{|c|}{ Reversed sum of differences: 19} & \\
\hline \multirow[t]{2}{*}{2} & $\begin{array}{l}\text { Wider variety of product and } \\
\text { service offerings }\end{array}$ & 3 & 1 & 5 & 4 & 5 & 1 & $\begin{array}{l}\text { Specialist provider of } \\
\text { bespoke offerings }\end{array}$ & \multirow{2}{*}{ L } \\
\hline & \multicolumn{2}{|c|}{ Sum of differences: 13} & \multicolumn{2}{|c|}{ imilarity score: $-8 \%$} & \multicolumn{2}{|c|}{ Reversed sum of differences: 9} & \multicolumn{2}{|c|}{ Reversed similarity score: $25 \%$} & \\
\hline \multirow[t]{2}{*}{3} & Local (Ireland) & 1 & 1 & 4 & 4 & 4 & 3 & UK or beyond & \multirow{2}{*}{ L } \\
\hline & \multicolumn{2}{|c|}{ Sum of differences: 15} & \multicolumn{2}{|c|}{ Similarity score: $-25 \%$} & \multicolumn{2}{|c|}{ Reversed sum of differences: 9} & \multicolumn{2}{|c|}{ Reversed similarity score: $25 \%$} & \\
\hline \multirow[t]{2}{*}{4} & $\begin{array}{l}\text { Effective - get desired } \\
\text { results }\end{array}$ & 4 & 2 & 1 & 2 & 1 & 2 & Ineffective results & \multirow{2}{*}{$\mathrm{H}$} \\
\hline & \multicolumn{2}{|c|}{ Sum of differences: 2} & \multicolumn{2}{|c|}{ Similarity score: $83 \%$} & \multicolumn{2}{|c|}{ Reversed sum of differences: 18} & \multicolumn{2}{|c|}{ Reversed similarity score: $-50 \%$} & \\
\hline \multirow[t]{2}{*}{5} & Phone support/advice & 3 & 3 & 1 & 1 & 1 & 2 & Poor phone support & \multirow{2}{*}{$\mathrm{H}$} \\
\hline & \multicolumn{2}{|c|}{ Sum of differences: 3} & \multicolumn{2}{|c|}{ Similarity score: $75 \%$} & \multicolumn{2}{|c|}{ Reversed sum of differences: 17} & \multicolumn{2}{|c|}{ Reversed similarity score: $-42 \%$} & \\
\hline 6 & On-time delivery & 2 & 2 & 3 & 2 & 1 & 2 & Poor on-time delivery & 1 \\
\hline 7 & Reasonable cost & 3 & 4 & 3 & 2 & 1 & 4 & Expensive cost & 1 \\
\hline & Sum of difference & & larity score: & & Reversed sum & differences: 1 & $\operatorname{Rev}$ & sed similarity score: $8 \%$ & 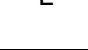 \\
\hline 8 & Good customer support & 2 & 1 & 2 & 1 & 1 & 2 & Poor customer support & 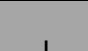 \\
\hline & Sum of difference & & larity score: & & Reversed sun & differences: & Rever & d similarity score: $-42 \%$ & 1 \\
\hline
\end{tabular}

\begin{tabular}{|c|c|c|c|c|c|c|c|c|}
\hline Supplied Construct & Satisfied & 4 & 2 & 1 & 1 & 1 & 1 & Dissatisfied \\
\hline & Reversed Ratings & 2 & 4 & 5 & 5 & 5 & 5 \\
\hline
\end{tabular}

\section{H-I-L Index Calculation}

\begin{tabular}{|c|c|c|c|c|c|c|c|}
\hline Highest similarity score & 92 & \multicolumn{2}{|c|}{ High } & \multicolumn{2}{|c|}{ Intermediate } & \multicolumn{2}{|c|}{ Low } \\
\hline Lowest similarity score & 25 & $\begin{array}{c}\text { Upper } \\
\text { boundary }\end{array}$ & $\begin{array}{c}\text { Lower } \\
\text { boundary }\end{array}$ & $\begin{array}{c}\text { Upper } \\
\text { boundary }\end{array}$ & $\begin{array}{c}\text { Lower } \\
\text { boundary }\end{array}$ & $\begin{array}{c}\text { Upper } \\
\text { boundary }\end{array}$ & $\begin{array}{c}\text { Lower } \\
\text { boundary }\end{array}$ \\
\hline & & 92 & 69 & 68 & 47 & 46 & 25 \\
\hline
\end{tabular}

Figure 2: Example Repertory Grid (shaded areas represent results of Honey calculations) 
Table 1: Coding Process and Reliability Checks

\begin{tabular}{cccccc}
\hline & Initial Coding & $\begin{array}{c}\text { Defining } \\
\text { Construct } \\
\text { Categories }\end{array}$ & Re-coding & Independent Checks \\
\hline $\begin{array}{c}\text { Coding Time } \\
\text { Spent }\end{array}$ & 26 hours & 16 hours & 16 hours & 8 hours & 10 hours \\
$\begin{array}{c}\text { Researchers } \\
\text { Involved }\end{array}$ & $\mathrm{R}_{1}, \mathrm{R}_{2}$ & $\mathrm{R}_{1}, \mathrm{R}_{2}$ & $\mathrm{R}_{1}, \mathrm{R}_{2}$ & $\mathrm{R}_{3}$ & $\mathrm{R}_{4}$ \\
$\begin{array}{c}\text { Reliability } \\
\text { Checks Time }\end{array}$ & 10 hours & N/A & 6 hours & 4 hours & 4 hours \\
$\begin{array}{c}\text { Inter-rater } \\
\text { Reliability } \\
\text { (IRR) }\end{array}$ & $48 \%$ & N/A & $86 \%$ & $78 \%$ & $83 \%$ \\
\hline
\end{tabular}

N/A, not applicable

\section{Identification of Key Attributes of Value-in-Use}

The 33 interviews produced 272 constructs that were coded into the final 29 categories shown in Table 2. The most frequently mentioned construct category was knowledge (mentioned by $76 \%$ respondents), the second most mentioned was responsiveness (mentioned by $67 \%$ of respondents).

\begin{tabular}{|c|c|c|c|c|}
\hline No. & Construct category & $\begin{array}{c}\text { Overall } \\
\text { Frequency } \\
(\%)\end{array}$ & $\begin{array}{c}\text { Average } \\
\text { Normalized } \\
\text { Variability } \\
\text { (ANV) }\end{array}$ & $\begin{array}{c}\text { Key } \\
\text { construct } \\
\text { category? }\end{array}$ \\
\hline 1. & Knowledge & 76 & 13.24 & Yes \\
\hline 2. & Responsiveness & 67 & 9.62 & No \\
\hline 3. & Access & 55 & 16.00 & Yes \\
\hline 4. & Relational dynamic & 45 & 12.4 & Yes \\
\hline 5. & Range of product and service offerings & 42 & 15.00 & Yes \\
\hline 6. & Understanding customer business & 42 & 10.63 & No \\
\hline 7. & Service orientation & 39 & 11.95 & No \\
\hline 8. & Delivery & 39 & 12.5 & Yes \\
\hline 9. & Price & 36 & 13.66 & Yes \\
\hline 10. & Convenience & 33 & 9.63 & No \\
\hline 11. & Locality & 33 & 17.7 & Yes \\
\hline 12. & Quality of repairs & 33 & 7.18 & No \\
\hline 13. & Feedback and reporting & 33 & 11.87 & No \\
\hline 14. & Communication & 27 & 10.11 & No \\
\hline 15. & Control & 24 & 15.31 & No \\
\hline 16. & Reliability & 21 & 10.01 & No \\
\hline 17. & Innovation & 21 & 12.73 & No \\
\hline 18. & Cost & 21 & 12.14 & No \\
\hline 19. & Urgency & 21 & 12.07 & No \\
\hline 20. & Support systems & 18 & 10.25 & No \\
\hline 21. & Administration & 18 & 8.98 & No \\
\hline
\end{tabular}




\begin{tabular}{llccc}
\hline 22. & Ability to source & 15 & 8.09 & No \\
\hline 23. & Inventory management & 15 & 15.39 & No \\
\hline 24. & Pro-active & 15 & 12.72 & No \\
\hline 25. & Detailed analysis & 9 & 9.6 & No \\
\hline 26. & Traceability & 9 & 14.05 & No \\
\hline 27. & Risk & 9 & 17.45 & No \\
\hline 28. & Quality of equipment & 9 & 6.71 & No \\
\hline 29. & Contract & 9 & 13.87 & No \\
\hline
\end{tabular}

Table 2: Categories of Constructs from Repertory Grid Interviews (construct categories mentioned by $>25 \%$ of respondents and variability greater than average are highlighted).

Frequency of mention is often used as a measure of importance but this interpretation has been strongly criticized (Griffin and Hauser, 1993). This is because frequently mentioned constructs can be "obvious, easily articulated, and of low importance" (Goffin and Koners, 2011, p. 307). A more reliable approach to determine key construct categories is to complement frequency of mention with a second criterion, average normalized variability (ANV) (Goffin et al., 2006). This requires the variability figures from different grids to be normalized, to make them comparable.

The average number of constructs per grid was 8.24 (i.e. $272 \div 33$ ), which resulted in an average variability of constructs of 12.13 (i.e. $100 \div 8.24$ ). Thus, a construct category with an ANV greater than 12.13 indicates that the construct differentiates more strongly between the different suppliers of integrated products and services. Conversely, a construct with an ANV less than 12.13 indicates that the construct category differentiates less strongly between suppliers. So answering RQ1, the two construct categories mentioned by $25 \%$ or more of respondents and higher than average ANV (i.e. $>12.13$ ) were deemed key. Applying these two criteria (see shading on Table 2) identified seven key attributes of value-in-use for integrated product service combinations: knowledge, access, relational dynamic, range of product and service offerings, delivery, price, and 
locality (see Table 2 Column 5 'Key Category?'). The meaning of each of these is explained in Appendix 1.

\section{RESULTS OF STAGE 2: IMPACT ON CUSTOMER SATISFACTION}

This stage focused on RQ2 and calculated the impact of the attributes of value-in-use on customer satisfaction. The seven key attributes identified in Stage 1 were subjected to further detailed analysis using the Honey procedure. This is based on the supplied construct—“satisfied - dissatisfied"—used at the end of every interview (see Figure 2), against which respondents rated the performance of their suppliers. In the analysis, the supplied construct (designated $c^{\prime}$ in formulae discussed later) formed a benchmark against which each elicited construct (designated $c$ in formulae) could be compared. As the same supplied construct was used across all interviews, this also enabled comparisons across different grids.

\section{Honey's Content Analysis}

Two grids had to be excluded from Stage 2 because these two respondents failed to rate the supplied construct. Therefore a total of 31 grids and 258 constructs were analyzed using Honey's procedure which was further enhanced in this article using ideas from both Jankowicz (2004) and Shcheglova (2009). The calculations from this procedure are presented in the example Repgrid with Honey's scores marked (see Figure 2). The full procedure had seven steps: 
Step 1: The respondent's ratings on the supplied construct were reversed. In Figure 2, for example, it can be seen that Supplier 1 was rated as ' 4 ' against the supplied construct and when this was reversed on the 1-5 scale this became a ' 2 '. This was repeated for each rating and so Supplier 2 which was rated ' 2 ' against the supplied construct led to a reversed rating of ' 4 '. On Figure 2 it can be seen that the row of reversed ratings has values '2', '4', '5', '5', '5' and '5', corresponding to the Suppliers 1-6.

Step 2: The analysis proceeded with the calculation of the first of three important indices: the sum of differences (Dcc'). This index is calculated for each elicited construct and enabled us to identify the elicited constructs that were closest to the supplied construct ("satisfied - dissatisfied"). The index was calculated by taking sum of absolute differences between the ratings of the supplied construct and the ratings of each elicited construct. For example, the sum of differences for Construct Number 1 in the example grid (Figure 2) was calculated as follows:

Sum of differences $($ Construct 1$)=|4-4|+|2-2|+|1-1|+|2-1|+|1-1|+|1-1|=1$

The sum of differences needed to be calculated not only for the ratings against the supplied construct but also for the reversed ratings. For Construct Number 1 the reversed sum of differences was calculated as follows:

Reversed Sum of differences (Construct 1) $=|4-2|+|2-4|+|1-5|+|2-5|+|1-5|+|1-5|=19$

In the shaded areas below each elicited construct in Figure 2, it can be seen that the sum of differences for Construct Number 1 was '1' (Reversed sum of differences '19'), and for Construct Number 2 it was '13' (Reversed sum of differences '9'), etc. Note that the 
sum of differences was calculated for both "unreversed" and "reversed" ratings. The sum of differences for construct $c$ with respect to ratings of the supplied construct $c^{\prime}$ is designated Dcc' and the formula used was:

$$
\mathrm{D} c c^{\prime}=\sum_{e=1}^{E}\left|c e-c^{\prime} e\right|
$$

Where: $\quad e$ is the number of each element

$E$ is the total number of elements in the grid $c e$ is the rating assigned to element number $e$ with respect to the construct $c$ $c^{\prime} e$ is the rating assigned to element number $e$ with respect to the supplied construct $c^{\prime}$

Step 3: The second important index: percentage similarity score (Pcc') was calculated. This index used the sum of differences to measure the similarity between elicited constructs and the supplied construct. It also allowed data in different grids to be compared, regardless of the number of constructs elicited during an individual interview. The percentage similarity scores were calculated by adopting Shcheglova's (2009) formula:

$$
P c c^{\prime}=100 \%-\frac{200 \% \times D c c^{\prime}}{(m-1) \times E}
$$

Where: $m$ is the maximum possible rating (i.e. '5')

$(m-1)$ is the largest possible difference between ratings

$(m-1) \times e$ is the largest possible sum of differences between constructs in the whole grid

$E$ is the total number of elements in the grid

Again the calculation was made for both "unreversed" and "reversed values". For instance, the percentage similarity score for Construct Number 1 was: 


$$
100 \%-\frac{200 \% \times 1}{(5-1) \times 6}=92 \%
$$

And the reversed similarity score for Construct Number 1 was calculated to be:

$$
100 \%-\frac{200 \% \times 19}{(5-1) \times 6}=-58 \%
$$

Step 4: Having calculated "unreversed" and "reversed" values for the sum of differences (Step 2) and the similarity scores (Step 3), the data were structured further. Working through each construct in turn, the higher similarity score, either "reversed" or "unreversed", was identified and underlined to make them stand-out. For instance, in Figure 2 for Construct Number 1 the similarity score of $92 \%$ was selected and underlined, since it was higher than the reversed similarity score of $-58 \%$. For Construct Number 2 the underlined value was $25 \%$.

Step 5: This calculated the third important index: the H-I-L Index (High, Intermediate, and Low index; Jankowicz, 2004). For example, in Figure 2 the eight elicited constructs were divided into three groups in terms of their closeness to the supplied construct. The higher the index the closer the meaning between the elicited and supplied constructs (Bhatia and Yao, 1998; Jankowicz, 2004). In this research, the precision of the H-I-L index calculations was ensured by using the formulae of Shcheglova (2009), rather than relying on the personal judgment of the researcher in allocating H-I-L index in an arbitrary manner as proposed by Jankowicz (2004). Referring to Figure 2 it can be seen 
(see "H-I-L Calculation") that the range is between the highest underlined similarity score (92\% corresponding to Construct Number 1) and 25\% (corresponding to Construct Numbers $2 \& 3$ ). This range was divided into three equal intervals ('92 to 69'; '68 to 47'; and ' 46 to 25 '). The formulae used in calculating this are shown in Table 3 below (where hi represents the highest percentage similarity score and li represents the lowest percentage similarity score in a given grid).

\begin{tabular}{|c|c|c|c|c|c|}
\hline \multicolumn{2}{|c|}{ High } & \multicolumn{2}{|c|}{ Intermediate } & \multicolumn{2}{c|}{ Low } \\
\hline Upper boundary & Lower boundary & Upper boundary & Lower boundary & Upper boundary & Lower boundary \\
\hline$\overline{\mathrm{Hi}}=\mathrm{hi}$ & $\underline{\mathrm{Hi}}=\mathrm{li}+\frac{2(\mathrm{hi}-\mathrm{li})}{3}$ & $\overline{\mathrm{Ii}}<\mathrm{li}+\frac{2(\mathrm{hi}-\mathrm{li})}{3}$ & $\underline{\mathrm{I} i}=\mathrm{li}+\frac{\mathrm{hi}-\mathrm{li}}{3}$ & $\overline{\mathrm{Li}}<\mathrm{li}+\underline{\mathrm{hi}-\mathrm{li}}$ & $\underline{\mathrm{Li}}=\mathrm{li}$ \\
& & & & \\
\hline
\end{tabular}

Table 3: Interval calculations for H-I-L index

Step 6: The next step in Honey's procedure involved the allocation of H-I-L index for each elicited construct. This was determined by which interval the construct's similarity scores falls within. In Figure 2 for example, Construct Number 1 had an underlined similarity score of $92 \%$ which was in the range of the High index. This indicated that Construct Number 1 was strongly related to the supplied construct. In other words, Construct Number 1 was identified to have a strong impact on customer satisfaction. In contrast, Construct Number 2 had an underlined similarity score of $25 \%$ which meant that it was found to have a low impact on the supplied construct. Thus, the H-I-L scores for each construct are presented in Figure 2 in the far right column. 
Step 7: After repeating the same procedure (Steps 1-6) for every one of the 31 individual grids, the data across the grids were aggregated in order to answer RQ2 and identify the impact of elicited constructs on customer satisfaction. These results are discussed next.

\section{Impact of Value-in-Use Attributes on Customer Satisfaction}

The key advantage of Honey's Content Analysis is that it reveals how elicited constructs are related to a supplied construct. In this research, this allowed the impact of different attributes of value-in-use on customer satisfaction to be determined (RQ2).

Stage 1 identified seven attributes of value-in-use, based on frequency and ANV (see Table 2). In this knowledge emerged as the most frequently mentioned attribute. However, according to H-I-L scores, this attribute does not have the most impact on customer satisfaction. Table 4 shows the full results of the Honey procedure and it can be seen that the two attributes which had the greatest impact on customer satisfaction were relational dynamic (53\% $\mathrm{H}$ index) and access $(50 \% \mathrm{H}$ index). The attributes that follow, that is range of product and service offerings $(42 \% \mathrm{H}$ index $)$, price $(33 \% \mathrm{H}$ index), knowledge $(32 \% \mathrm{H}$ index) and delivery $(31 \% \mathrm{H}$ index) were found to be moderately linked to customer satisfaction while locality $(18 \% \mathrm{H}$ index $)$ was found to have the least impact.

\begin{tabular}{|c|c|c|c|c|c|}
\hline No. & Construct category & $\begin{array}{c}\text { Overall } \\
\text { Frequency }(\%)\end{array}$ & $\mathrm{H}$ & $\begin{array}{l}\mathrm{I} \\
\%\end{array}$ & $\mathrm{~L}$ \\
\hline 1 & Relational dynamic & 45 & 53 & 33 & 13 \\
\hline 2 & Access & 55 & 50 & 31 & 19 \\
\hline 3 & Range of product and service offerings & 42 & 42 & 33 & 25 \\
\hline 4 & Price & 36 & 33 & 42 & 25 \\
\hline 5 & Knowledge & 76 & 32 & 18 & 50 \\
\hline 6 & Delivery & 39 & 31 & 23 & 38 \\
\hline 7 & Locality & 33 & 18 & 27 & 55 \\
\hline
\end{tabular}

Table 4: Honey's Content Analysis for Key Value-in-Use Attributes 
Having identified that relational dynamic and access had the greatest impact on customer satisfaction, the qualitative data for these two categories of construct were expanded and these are given in Table 5. In this table, the constructs are listed with corresponding scores: frequency, ANV, similarity score and H-I-L index scores. This rich data offers a deeper picture of the meaning behind these construct categories.

\section{Relational Dynamic}

Most respondents placed high emphasis on the need for a "person-to-person relationship based on working in partnership" (Company C, Respondent 2-6). For example, “...there's a sense of trust there that they know if they get me something, then they're paid for it the next day" (Company B, Respondent 3-6). This demonstrates a sense of mutual obligation and interests. Another respondent emphasized the need for a personal and individual relationship: “...they don't manage the client actively, you're just one of the many and you very much feel like that, there's no differentiation of you as a client" (Company B, Respondent 2-2). These insights show that the providers of integrated offerings need to develop a relational approach, that is, underpinned by trust and working in partnership with customers.

\section{Access}

There were two aspects of access to emerge from respondents: time availability and colocation. The first of which concerns the access outside of standard business hours: “...they'd come in and they'd look at the problem, no bother for them; weekday, weekend or bank holiday" (Company C, Respondent 9-7). The latter aspect was frequently 
mentioned by respondents as "onsite vs. offsite access". According to them the problems associated with offsite location could be neutralized by the quickness of response as and when required, which was reflected in such constructs as "easy to get hold of" (Company B, Respondent 6-8) and "flexible service time for emergency" (Company C, Respondent 5-7). These insights show that providers of integrated products and services do not necessarily need to be co-located with customers but easily accessible as and when needed to satisfy needs. 


\begin{tabular}{|c|c|c|c|c|c|c|c|}
\hline No. & $\begin{array}{l}\text { Construct } \\
\text { Category }\end{array}$ & $\begin{array}{c}\text { Customer } \\
(\mathrm{A}, \mathrm{B}, \mathrm{C} \& \\
\text { D) }\end{array}$ & Bi-polar constructs & $\begin{array}{c}\text { Overall } \\
\text { Frequency } \\
(\%)\end{array}$ & $\begin{array}{c}\text { Average } \\
\text { Normalized } \\
\text { Variability }\end{array}$ & $\begin{array}{c}\text { Percentage } \\
\text { Similarity } \\
\text { Score } \\
(\%)\end{array}$ & $\begin{array}{l}\text { H- } \\
\text { I-L }\end{array}$ \\
\hline \multirow[t]{15}{*}{1.} & Relational & A2-6 & Strategic relationship - Admin relationship & 45 & 12.40 & 100 & $\mathrm{H}$ \\
\hline & Dynamic & A8-9 & Long-term relationship - short-term relationship & & & 83 & $\mathrm{H}$ \\
\hline & & A9-1 & Very obliging - corporate machine & & & 42 & I \\
\hline & & B2-2 & Personal touch - transactional & & & 58 & I \\
\hline & & B3-6 & History/Trust - unknown & & & 42 & I \\
\hline & & B6-3 & Telepathic - Not the relationship/transactional & & & 92 & $\mathrm{H}$ \\
\hline & & B7-5 & Personal relationship - impersonal & & & 42 & $\mathrm{~L}$ \\
\hline & & B8-2 & Direct relationship with their service - not direct & & & 63 & $\mathrm{~L}$ \\
\hline & & B9-4 & Good client management - poor client management & & & 79 & $\mathrm{H}$ \\
\hline & & C1-9 & $\begin{array}{l}\text { Good (person-to-person) business relationship - } \\
\text { transactional }\end{array}$ & & & 67 & $\mathrm{H}$ \\
\hline & & $\mathrm{C} 2-6$ & Working in partnership - working separately & & & 80 & $\mathrm{H}$ \\
\hline & & C5-4 & Quality of relationship (Hi) - No relationship & & & 81 & $\mathrm{H}$ \\
\hline & & C7-6 & Length of relationship - Not so long relationship & & & 57 & I \\
\hline & & D1-7 & Good relational skills - Poor relational skills & & & 69 & $\mathrm{H}$ \\
\hline & & D8-3 & Durable relationship - short-term & & & 69 & I \\
\hline \multirow[t]{12}{*}{2.} & Access & A3-3 & 24hr cover - Business hours & 55 & 16.00 & 67 & $\mathrm{H}$ \\
\hline & & A7-3 & Onsite - offsite & & & 92 & $\mathrm{H}$ \\
\hline & & A8-2 & $\begin{array}{l}\text { Easy to access supplier - not easy to access or deal } \\
\text { with }\end{array}$ & & & 75 & $\mathrm{H}$ \\
\hline & & B1-4 & Onsite - offsite & & & 33 & $\mathrm{~L}$ \\
\hline & & B2-5 & Come in and look at problem - cannot come on site & & & 50 & I \\
\hline & & B5-3 & Routinely on site - On-site only when needed & & & 25 & $\mathrm{~L}$ \\
\hline & & B6-8 & Easy to get hold of - Difficult to reach & & & 75 & $\mathrm{H}$ \\
\hline & & B7-8 & $\begin{array}{l}\text { On-site/personal contact - Offsite/No idea who you are } \\
\text { dealing with }\end{array}$ & & & 63 & I \\
\hline & & $\mathrm{C} 2-2$ & $24 / 7$ service $-9-17$ service & & & N/A & - \\
\hline & & $\mathrm{C} 3-7$ & Site based availability - Call when needed & & & N/A & - \\
\hline & & $\mathrm{C} 4-1$ & $\begin{array}{l}\text { Easy to get on site - Very difficult to get someone on- } \\
\text { site }\end{array}$ & & & 79 & $\mathrm{H}$ \\
\hline & & $\mathrm{C} 5-2$ & Frequent on-site interaction - Lack of interaction & & & 64 & I \\
\hline
\end{tabular}


personal communication

C5-7 Instant service (flexible service time for emergency) -

Fixed service time, booked in advance

C9-7 24/7-No out of hour service

D1-1 Access based on service agreement - No service

D4-2 24HR - Not available out of hours

D5-1 Regularly onsite/easy to access - ad-hoc

Table 5: Relational dynamic and access construct categories with corresponding Honey scores 


\section{DISCUSSION AND CONCLUSIONS}

\section{Understanding Integrated Products and Services}

Not enough is known about integrated products and services because the majority of previous studies have concentrated on products or services separately. It is the integration of the two which needs to be better understood. Consequently, this article describes exploratory insights; the research aimed to identify the key attributes of value-in-use for integrated products and services [RQ1] and how these attributes impact customer satisfaction [RQ2].

In answering RQ1, 29 construct categories of value-in-use were identified and seven were determined to be key attributes: knowledge, access, relational dynamic, range of product and service offerings, delivery, price, and locality. Through the methodology used, an indepth understanding of each of these attributes emerged (see Table 5 and Appendix 1) and, for example, the importance of a dynamic relationship between the customer and the solutions provided was identified. This is in stark contrast to the static and standard attributes of aftersales support identified by previous research (e.g. Goffin and New, 2001). Of particular note in this article is the key attribute knowledge. For example, customers were found to not only value knowledge about the equipment but also wanted them provider to understand their processes and help them improve business performance. Customers also emphasized the need for a range of product and service offerings customized to their specific needs. Coupled with this, the ability of the provider to negotiate with other suppliers on price to reduce costs was found to be an important consideration. Another example was customers requiring providers to integrate not only their products and services but also to integrate them with products from third party suppliers, to offer more comprehensive solutions. Providers were expected by customers to be willing to integrate not only their own products into their solutions but the products of competitors. 
Previous research has stressed that after-sales requirements must be fully considered during NPD, so that products are designed that are, for example, easy to install, learn, operate, maintain and repair. However, the current research shows the importance of the type of services that are integrated with the product. The customer needs identified in this article shows that providers must work closely with customers to co-define the type of service needed. Manufacturers need to develop a deep understanding of their customers' businesses in order to focus on the attributes that will lead to value-in-use.

Customer satisfaction is a strategic priority for many manufacturers. In answering RQ2 it became clear that two attributes-relational dynamic and access-have the greatest impact on customer satisfaction. Therefore, integrated product and service providers need to design their offerings accordingly. These offerings need to be less static and standard than those recommended in the extant literature. Instead they need to be customized and able to evolve. This represents a key contribution of this article to the innovation literature and the discussion on the unity between product and service during design (Creuasen, 2011).

The picture of the key attributes of value-in-use obtained in this research shows the importance of soft skills in integrated product and service delivery. Most aspects comprising relational dynamic are traditional soft skills such as communication, personal relationships, trust and partnership. This contributes to previous discussions on the importance of soft skills and training in the literature on integrated products and services (cf. Storbacka, 2011; Bastl et al., 2012; Santamaria et al., 2012).

\section{Methodological Contribution}

This article contributes to the overall methodology of the Repertory Grid Technique by presenting Honey's procedure (1979) in a more systematized way. This was achieved by the incorporation of two formulae from Shcheglova (2009) Details of this modified approach 
were published here for the first time and will enable other researchers to apply the approach. It is an approach that combines qualitative and quantitative insights, allowing researchers to understand the meanings, importance, and impact of elicited constructs.

Overall, using multiple grid analysis juxtapositioned with Honey`s Content Analysis offers a rare but rich mix of quantitative and qualitative insights (Jankowicz, 2004). Normally quantitative methods such as surveys can identify key factors but then do not provide the rich, detailed explanations of constructs—-nor do they capture this meaning in the original words of respondents, as illustrated by Table 5 and Appendix 1 .

\section{Managerial Implications}

This research leads to four main managerial implications:

- Seven key attributes of value-in-use need to be considered during the development of integrated products and services. These need to be given emphasis, as too many companies focus on product specifications and largely overlook service requirements.

- Two attributes_relational dynamic and access-have the greatest impact on customer satisfaction and so integrated product and service providers need to design their offerings giving special consideration to these. As the relationships with customers are dynamic, manufacturers need to be aware they may need to design dynamic services e.g. integrated services that evolve as a closer relationship is established.

- Manufacturers must perceive themselves as providers of integrated solutions and to achieve this they need to develop new competencies and capabilities. Staff should be cognizant of changing customer needs, relating to both the product and the (evolving) service. To develop such an organizational capability, companies will need to enhance their staff training and development programs. This implication has a particular bearing on human resource departments and the policies and practices necessary for the 
development of new skills in manufacturing organizations providing complex solutions to customer needs ( $c f$. Raja et al., 2010; Storbacka, 2011; Santamaria et al., 2012).

- The Repertory Grid Technique described in this article is a tool that can be adopted by practitioners. It will enable them to identify the key attributes of value-in-use and their impact on customer satisfaction, in specific industries and for specific customers (thus enabling customization of services).

\section{Limitations}

This research is limited by the context and the four customer organizations studied. Therefore, the empirical data should not be taken as representative of all sectors and customers. Furthermore, potential differences between the views of buyers and users of integrated product and service offerings were not explored.

\section{Implications for Further Research}

This article has demonstrated the need for further research into value-in-use and satisfying customer needs in the provision of integrated products and services. Since little is known about how customer needs evolve over time, more longitudinal research is needed in order to aid our understanding of the dynamic and complex nature of customer expectations.

The findings of this study may be tested in other industrial contexts with a larger sample of companies. Future research may operationalize the identified attributes using survey research to explore relationships amongst them. This will then allow researchers to identify context independent attributes which then will lead to generalizable propositions.

Another field for future research is different views on integrated products and services: buyers and users may have different expectations, and these may change over time. 


\section{SUMMARY}

Leading manufacturers recognize that complex products need to be integrated with suitable services. Integrated products and services can generate increased revenues and achieve customer satisfaction. During new product and service development, special steps need to be taken to consider how to create integrated products and services. This requires a clear understanding of how customers perceive the value they obtain from products and servicesso-called value-in-use. An exploratory study was made of how customers perceive value-inuse. Structured interviews using Repertory Grid Technique gathered data from 33 respondents. The data allowed the key attributes of value-in-use to be identified. In addition, the impact of the different attributes of value-in-use on customer satisfaction was identified. Two key attributes — relational dynamic and access — that were found to have the most impact on customer satisfaction. This research shows there are important customer needs related to integrated products and services and how these impact customer satisfaction. These are key points for managers to fully consider during new product and service development and should also stimulate researchers to probe further. 
Appendix 1: Key Attributes of Value-in-Use

\begin{tabular}{|c|c|c|}
\hline Key attribute & Indicative factors & Illustrative quotes \\
\hline Knowledge & $\begin{array}{l}\text { Technical knowledge; expert } \\
\text { knowledge and skills; specialist } \\
\text { contractor; knowledge of product } \\
\text { and processes; know-how; bringing } \\
\text { outsider knowledge to the company; } \\
\text { technical assistance/support; } \\
\text { applying knowledge to improve } \\
\text { machine performance; design } \\
\text { improvement advice; sharing } \\
\text { knowledge and ideas. }\end{array}$ & $\begin{array}{l}\text { "...they need to be able to tackle specific problems, otherwise there is a } \\
\text { learning curve." } \\
\text { "...we scored technical knowledge way ahead because we need that } \\
\text { knowledge on-site, especially on the tool end side of the business, so that } \\
\text { would be very important to us." } \\
\text { "...better to have specialist then daily support..." } \\
\text { "...coming up with ideas; not being scared or whatever to bring it to the } \\
\text { table; sharing what they know" }\end{array}$ \\
\hline Access & $\begin{array}{l}\text { Accessible as and when we need } \\
\text { them; available outside of normal } \\
\text { business hours; access to range of } \\
\text { suppliers. }\end{array}$ & $\begin{array}{l}\text { "...it is important that suppliers are accessible as and when we need } \\
\text { them" } \\
\text { "...they'd come in and they'd look at the problem, no bother for them; } \\
\text { weekday, weekend or bank holiday". } \\
\text { "easy to get hold of" }\end{array}$ \\
\hline Relational dynamic & $\begin{array}{l}\text { Direct business relationship; } \\
\text { duration of relationship; obliging; } \\
\text { quality of relationship; relational } \\
\text { skills; trust; working in partnership; } \\
\text { quality of relationship with supplier; } \\
\text { good client management; relational } \\
\text { history; manipulate to get support. }\end{array}$ & $\begin{array}{l}\text { “...they are very obliging to ensure there is a good relationship.” } \\
\text { “...there's a sense of trust there that they know if they get me something, } \\
\text { then they're paid for it the next day” } \\
\text { “...there are some things that happen and you don't find out about them, } \\
\text { so they don't manage the client actively, you're just one of the many and } \\
\text { you very much feel like that, there's no differentiation of you as a client." } \\
\text { “...they rely on me to approach them to order the part and if they don't } \\
\text { see me from one end of the year to the next, they are not going to contact } \\
\text { me and ask if I have left the company.” } \\
\text { "person-to-person relationship based on working in partnership." }\end{array}$ \\
\hline $\begin{array}{l}\text { Range of product and } \\
\text { service offerings }\end{array}$ & $\begin{array}{l}\text { Choice of product and service } \\
\text { offerings; developing preventative } \\
\text { maintenance offerings; spare parts } \\
\text { and resources provision; specialist } \\
\text { equipment service provider; } \\
\text { providing different types of support; } \\
\text { building and commissioning } \\
\text { services; better offerings compared } \\
\text { to competitors. }\end{array}$ & $\begin{array}{l}\text { “...being able to cover majority of repairs" } \\
\text { "able to give you range and give you a couple of different options..." } \\
\text { "From my perspective-as a commercial side-the more options I've got } \\
\text { the better." } \\
\text { "...they are a one stop shop when it comes to the type of products and } \\
\text { maintenance services we require..." }\end{array}$ \\
\hline Delivery & $\begin{array}{l}\text { Meeting delivery targets/dates; } \\
\text { flexible on-time delivery; expediting } \\
\text { orders; lead times; managing time } \\
\text { constraints; no delays. }\end{array}$ & $\begin{array}{l}\text { "...they deliver as agreed" } \\
\text { "...they might take } 24 \text { hours for you to get a delivery date, the one thing I } \\
\text { will say for them is when they give you that delivery date it is held to." } \\
\text { "If we need the parts, we need them now. We try not to cry wolf unless } \\
\text { there is something very important which most of the suppliers do. They } \\
\text { just have to supply it as long as they can supply it on-time." }\end{array}$ \\
\hline Price & $\begin{array}{l}\text { More value for fixed price; } \\
\text { accessible price; competitive price; } \\
\text { negotiate on price; negotiating better } \\
\text { deals with suppliers; not charging } \\
\text { for extras. }\end{array}$ & $\begin{array}{l}\text { "...it is difficult to negotiate price because they know that I suppose our } \\
\text { hands are tied because of the fact that we're in the pharmaceutical sector, } \\
\text { they know the autoclaves on our filling lines that we would need their } \\
\text { parts, so it's difficult to negotiate pricing with them." } \\
\text { "...they are not committed to reducing costs for [us], they are about } \\
\text { abusing us on price” } \\
\text { "...before allowing them to do more service an important consideration } \\
\text { would be the competitive cost" }\end{array}$ \\
\hline
\end{tabular}




Locality $\begin{aligned} & \text { Location; distance from } \\ & \text { plant/operations; proximity to } \\ & \text { customer. }\end{aligned}$
"....they are not a long distance away from us.

\section{REFERENCES}

Alam, I. 2006. Removing the Fuzziness from the Fuzzy-End of Service Innovations through Customer Interactions. Industrial Marketing Management 35 (4):468-80.

Anderson, E.W. and Sullivan, M.W. 1993. The andecedents and consequences of customer satisfaction for firms. Marketing Science 12 (2): 125-143.

Armistead, C.G. and Clark, G. 1992. Customer Service and Support. Pitman, London.

Baines, T., Lightfoot, H., Evans, S., Neely, A., Greenough, R., Peppard, J., Roy, R., Shehab, E., Braganza, A., Tiwari, A., Alcock, J. R., Angus, J. P., Bastl, M., Cousens, A., Irving, P., Johnson, M., Kingston, J., Lockett, H., Martinez, V., Michele, P., Tranfield, D., Walton, I. M., and Wilson, H. 2007. State-of-the-art in product-service systems, Proc. IMechE: J. Engineering Manufacture, 221, Part B, 1543-1552.

Baines, T., Lightfoot, H., Peppard, J., Johnson, M., Tiwari, A., Shehab, E., and Morgan, S. 2009. Towards an operations strategy for product-centric servitization, International Journal of Operations and Production Management, 29 (5), 494-519.

Bastl, M., Johnson, M., Evans, S., Lightfoot, H. 2012. Buyer-Seller relationships in a servitized environment: an examination with Cannon and Perreault's framework. International Journal of Operations \& Production Management, 32 (6), 650-675.

Bell, R. 2009. Griddled with Angst: A Roller-Coaster Ride on the Repertory Grid. In Butler, J ed. (2009) Reflections in Personal Construct Theory. Wiley-Blackwell.

Berg, J. and Loeb, J. 1990. The Role of Field Service in New Product Development and Introduction. AFSM International-The Professional Journal, 14 (9), 25-30.

Bhatia S. K. and Yao, Q. 1994. Analyzing Interval-Valued Repertory Grids. In J. W. Brahan and G. E. Lasker (eds.), Advances in Artificial Intelligence -- Theory and Applications, (vol. 2). International Institute for Advanced Studies in Systems Research and Cybernetics, Baden-Baden, Germany. August. 13-18.

Brady, T., Davies, A. and Gann, D. M. 2005. Creating value by delivering integrated solutions. International Journal of Project Management 23: 360-365.

Bundschuh, R. and Dezvane, T. 2003. How to make after-sales service pay off. McKinsey Quarterly, 4, 116-127.

Cannon, J.P. and Perreault, W.J.D. 1999. Buyer-seller relationships in business markets. Journal of Marketing Research 36 (4): 439-460.

Carbonell, P., Rodríguez-Escudero, A. I. and Pujari, D. 2009. Customer Involvement in New Service Development: An Examination of Antecedents and Outcomes. Journal of Product Innovation Management. 26: 536-550.

Cohen, M., Agrawal, N. and Agrawal, V. 2006. Winning in the aftermarket. Harvard Business Review 84(May): 129-138.

Cooper, R.G. 2001. Winning at New Products. Accelerating the Process from Idea to Launch. Cambridge, MA: Perseus.

Creusen, M. 2011 Research opportunities related to consumer response to product design. Journal of Product Innovation Management, 28(3), 405-408.

Davies, A., 2004. Moving base into high-value integrated solutions: a value stream approach. Industrial and Corporate Change 13 (5), 727-756. 
Davies, A., Brady, T. and Hobday, M. 2006. Charting a path towards integrated solutions. MIT Sloan Management Review Spring 38-49.

Desmet, S., Van Dierdonck, R. and Van Looy, B. 1998. Servitisation: the blurring boundaries between manufacturing and services, in B. Van Looy, R. Van Dierdonck and P. Gemmel (eds), Services Management: An Integrated Approach, London: Pitman Publishing.

Dobosz-Bourne, D. 2006. Reverse Diffusion of Quality: Evidence from General Motors UK and Poland. Journal for East European Management Studies, 11(3), 244-266.

Dobosz-Bourne, D. and Jankowicz, A.D. 2003. Knowledge Transfer of the Western Concept of 'Quality' Human Resource Development International, 5(3), 353-367.

Dröge, C., Jayaram, J. and Vickery, S. K. 2000. The Ability to Minimize the Timing of New Product Development and Introduction: An Examination of Antecedent Factors in the North American Automobile Supplier Industry. Journal of Product Innovation Management 17: 24-40.

Flint, D.J., Mentzer J.T., 2006. Striving for Integrated Value Chain Management Given a Service-Dominant Logic for Marketing, in: Lusch, R.F., Vargo, S.L. (eds.) The Service Dominant Logic of Marketing. M.E. Sharpe, London, pp. 139-149.

Foote, N.W., Galbraith, J., Hope, Q. and Miller, D. 2001. Making solutions the answer. The McKinsey Qaurterly 3: 84-93.

Franke, N. and Piller, F. 2004. Value Creation by Toolkits for User Innovation and Design: The Case of the Watch Market. Journal of Product Innovation Management 21: 401415.

Gebauer, H., Gustafsson, A. and Witell, L. 2011. Competitive advantage through service differentiation by manufacturing companies. Journal of Business Research 64 (12): 12701280.

Gerstner, L.V. 2002. Who said elephants can't dance? Inside IBM's historic turnaround, London: Harper Collins Publishers.

Goedkoop, M.J., van Halen, C.J.G., te Riele, H.R.M. and Rommens, P.J.M. 1999. ProductService Systems, ecological and economic basics. Report for Dutch Ministries of Environment (VROM) and Economic Affairs (EZ).

Goffin, K. 1998. Evaluating Customer Support During New Product Development - An Exploratory Study. Journal of Product Innovation Management 15 (1): 42-56.

Goffin, K. 1999. Customer Support: A Cross-Industry Study of Distribution Channels and Strategies. International Journal of Physical Distribution \& Logistics Management, 29 (6), 374-397.

Goffin, K., Lemke, F and Szwejczewski, M. 2006. "An Exploratory Study of 'Close' Supplier-Manufacturer Relationships". Journal of Operations Management, 24(1), 189209.

Goffin, K. and New, C. 2001. Customer support and new product development - an exploratory study. International Journal of Production and Operations Management, 21 (3): 275-301.

Goffin, K. and Koners, U. 2011. Tacit knowledge, lessons learnt, and new product development. Journal of Product Innovation Management.

Goffin, K., Raja, J.Z., Claes, B., Szwejczewski, M., Martinez, V. 2012. Rigor in qualitative supply chain management research - Lessons from applying repertory grid. International Journal of Physical Distribution \& Logistics Management 42 (9) awaiting page numbers.

Griffin, A. and Hauser, J.R. 1993. The Voice of the Customer. Marketing Science, 12(1), 1-27

Gulati, R. and Kletter, D. 2005. Shrinking core, expanding periphery; the relational architecture of high-performing organizations. California Management Review 47 (3): 77-104. 
Honey, P. 1979. The repertory grid in action, Industrial and Commercial Training, Nov 79, 11(11): 358--369; 407--414; 452-459

Hull, D.L. and Cox, J.F. (1994). The Field Service Function in the Electronics Industry: Providing a Link between Customers and Production/Marketing. International Journal of Production Economics, 37 (1), 115-126.

Jankowicz, D. 2004. The Easy Guide to Repertory Grids. John Wiley: Chichester, UK.

Jankowicz, A. D. 2001. Why Does Subjectivity Make Us Nervous? Making the Tacit Explicit. Journal of Intellectual Capital, 2(1), 61-73.

Johnstone, S., Dainty, A. and Wilkinson, A. 2009. Integrating products and services through life: an aerospace experience. International Journal of Operations and Production Management 29 (5): 520-538.

Karniouchina, E.V., Victorino, L., and Verma, R. 2006. Product and service innovation: Ideas for future cross-disciplinary research. Journal of Product Innovation Management, 23 (3): 274-80.

Kelly, G. A. 1955. The Psychology of Personal Constructs. (1st. ed.). New York: Norton.

Knecht, T., Lezinski, R. and Weber, F.A. 1993. Making Profits After the Sale, The McKinsey Quarterly, 4, 79-86.

Koners, U. and Goffin, K. 2007. Learning from post-project Reviews: A Cross-Case Analysis. Journal of Product Innovation Management, 24 (3), 242-258.

Langerak, F., Hultink, E. J. and Robben, H. S. 2004. The Impact of Market Orientation, Product Advantage, and Launch Proficiency on New Product Performance and Organizational Performance. Journal of Product Innovation Management 21: 79-94.

Lele, M.M. and Karmarkar, U.S. 1983. Good support is smart marketing. Harvard Business Review November-December 124-132.

Lele, M.M. and Sheth, J.N. (1987). The Customer is Key. Wiley, New York.

Lindberg, N. And Nordin, F. 2008. From products to services and back again: Towards a new service procurement logic. Industrial Marketing Management 37: 292-300.

Loomba, A.P.S. 1998. Product Distribution and Service Support Strategy Linkages: An Empirical Investigation. International Journal of Physical Distribution \& Logistics Management, 28 (2), 143-161.

Macdonald, E.K., Wilson, H., Martinez, V., and Toossi, A. 2011. Assessing value-in-use: A conceptual framework and exploratory study. Industrial Marketing Management 40 (5): 671-682.

Manzini, E. and Vezzoli, C. 2003. A strategic design approach to develop sustainable product service systems: examples taken from the 'environmentally friendly innovation' Italian prize, Journal of Cleaner Production, 11: 851-7.

Markeset, T. And Kumar, U. 2003. Design and development of product support and maintenance concepts for industrial systems. Journal of Quality in Maintenance Engineering 9 (4): 376-392.

Matthyssens, P., Vandenbempt, K. and Berghman, L. 2006. Value innovation in business markets: breaking the industry recipe. Industrial Marketing Management, 35 (6): 751-61.

Maxwell, D. and van der Vorst, R. (2003). Developing sustainable products and services, Journal of Cleaner Production, 11, 883-895.

Menor, L.J., Tatikonda, M.V. and Sampson, S.E. 2002. New service development: areas for exploitation and exploration. Journal of Operations Management 20: 135-157.

Menor, L.J. and Roth, A.V. 2007. New service development competence in retail banking: Construct development and measurement validation. Journal of Operations Management 25 (4): 135-57. 
Micheli, P., Jaina, J., Goffin, K., Lemke, F. and Verganti, R. 2012. "Perceptions of Industrial Design: The 'Means' and the 'Ends'”, Journal of Product Innovation Management, 29(5), 2012, 687-704.

Mont, O.K. 2002. Clarifying the concept of product-service system, Journal of Cleaner Production, 10, 237-245.

Morelli, N. 2003. Product-service systems, a perspective shift for designers: A case study: the design of a telecentre, Design Studies, 24, 73-99.

Oliva, R. and Kallenberg, R. 2003. Managing the transition from products to services. International Journal of Service Industry Management 14 (2): 160-172.

Ostrom, A.L., Bitner, M.J., Brown, S.W., Burkhard, M.G., Smith-Daniels, V., Demirkan, H, Rabinovich, E. 2010. Moving forward and making a difference: research priorities for the science of service, Journal of Service Research 13 (1), 4-36.

Penttinen, E. and Palmer, J. 2007. Improving firm positioning through enhanced offerings and buyer - seller relationships. Industrial Marketing Management 36 (5): 552-64.

Petersen, K. J., Handfield, R. B. and Ragatz, G. L. 2003. A Model of Supplier Integration into New Product Development. Journal of Product Innovation Management 20: 284-299.

Raja, J.Z., Green, S.D. and Leiringer, R. 2010. Concurrent and disconnected change programmes: strategies in support of servitization and the implementation of business partnering. Human Resource Management Journal, 20 (3): 258-276.

Santamaria, L., Nieto, M.J. and Miles, I. 2012. Service innovation in manufacturing firms: Evidence from Spain. Technovation 32 (2): 144-155.

Sawhney, M. 2004. Creating growth with services. Sloan Management Review, Winter 45 (2): 34-43.

Schleimer, S.C. and Shulman, A.D. 2011. A comparison of New Service versus New Product Development: Configurations of Collaborative Intensity as Predictors of Perfromance. Journal of Product Innovation Management, 28: 521-535.

Schmenner, R.W. 2009. Manufacturing, service, and their integration: some history and theory. International Journal of Operations \& Production Management 29 (5): 431 - 443.

Selnes, F. 1998. Antecedents and consequences of trusts and satisfaction in buyer-seller relationships. European Journal of Marketing 32 (3/4): 305-322.

Shankar, V., Berry, L.L. and Dotzel, T. 2010. A practical guide to combining products and services, Harvard Business Review 87 (11): 94-99.

Shcheglova, M. 2009. An Integrated Method to Assess Consumer Motivation in Difficult Market Niches: A Case of the Premium Car Segment in Russia. PhD Thesis. Technischen Universitat Berlin.

Shelton, R. 2009. Integrating product and service innovation. Research Technology Management 38-44.

Shepherd, C. and Ahmed, P.K. 2000. From product innovation to solutions innovation: a new paradigm for competitive advantage. European Journal of Innovation Management 3 (2): $100-6$.

Smith, M. 1986. An introduction to repertory grids, part one. Graduate Management Research 3 (1): 4-17.

Song, X. M., Di Benedetto, C. A. and Song, L. Z. 2000. Pioneering Advantage in New Service Development: A Multi-Country Study of Managerial Perceptions. Journal of Product Innovation Management 17: 378-392.

Souder, W. E. 1987. Managing New Product Innovations. Lexington, Mass: Lexington Books.

Stewart, V. and Stewart, A. 1982. Business Applications of Repertory Grid. London: McGraw Hill. 
Storbacka, K. 2011. A solution business model: Capabilities and management practices for integrated solutions, Industrial Marketing Management, 40 (5): 699-711.

Storey, C. and Easingwood, C.J. 1998. The augmented service offering: A conceptualization and study of its impact on new service success. Journal of Product Innovation Management 15: 335-351.

Sundin, E., Lindahl, M., and Ijomah, W. 2009. Product design for product/service systems: design experience from Swedish industry. Journal of Manufacturing Technology Management, 20 (5), 723-753.

Tikkanen, H., Alajoutsijärvi, K. and Tähtinen, J. 2000. The concept of satisfaction in industrial markets: A contextual perspective and a case study from the software industry. Industrial Marketing Management 29 (4): 373-386.

Tukker, A. 2004. Eight types of product service system; eight ways to sustainability? experiences from SUSPRONET, Business Strategy and the Environment, 13: 246-60.

Tuli, K. R., Kohli, A. K. and Bharadwaj, S. G. 2007. Rethinking customer solutions: From product bundles to relational processes. Journal of Marketing 71 (3): 1-17.

Vandermerwe, S. and Rada, J. 1988. Servitization of business: Adding value by adding services. European Management Journal 6 (4): 314-324.

Vandermerwe, S., 1990. The market power is in the services: because the value is in the results. European Management Journal 8 (4): 464-473.

Vandermerwe, S., 2000. How Increasing Value to Customers Improves Business Results. Sloan Management Review 42 (1): 27-38.

Vargo, S. and Lusch, R. 2004. Evolving to a new dominant logic for marketing. Journal of Marketing, 68 (1): 1-17.

von Hippel, E. 1998. The Sources of Innovation. New York: Oxford University Press.

Windahl, C. and Lakemond, N. 2006. Developing integrated solutions: the importance of relationships within the network, Industrial Marketing Management, 35 (7): 806-18.

Windahl, C. and Lakemond, N. 2010. Integrated solutions from a service-centered perspective: applicability and limitations in the capital goods industry, Industrial Marketing Management, 39(8): 1278-1290.

Windahl, C., Andersson, P., Berggren, C. and Nehler, C. 2004. Manufacturing firms and integrated solutions: characteristics and implications. European Journal of Innovation Management 7 (3): 218-28.

Wise, R. and Baumgartner, P. 1999. Go Downstream: The New Profit Imperative in Manufacturing. Harvard Business Review September-October: 133-141.

Woodruff, R.B. 1997. Customer value: The next source for competitive advantage. Journal of the Academy of Marketing Science, 25 (3): 139-153.

Woodruff, R.B. and Flint, D.J. 2006. Marketing's service-dominant logic and customer value, in The service-dominant logic of marketing: dialog, debate, and directions, R.F. Lusch \& S.L. Vargo, eds., Sharpe, New York.

Zeithaml, V.A., Parasuraman, A. and Berry, L. 1990. Delivering quality service: Balancing customer perceptions and expectations. New York: The Free Press.

Zomerdijk, L. G. and Voss, C. A. 2011. NSD Processes and Practices in Experiential Services. Journal of Product Innovation Management 28: 63-80. 